\title{
Lactobacillus rennini sp. nov., isolated from rennin and associated with cheese spoilage
}

Correspondence

Rosa Aznar

rosa.aznar@uv.es

\author{
Empar Chenoll, ${ }^{1,2}$ M. Carmen Macián ${ }^{2}$ and Rosa Aznar ${ }^{1,2}$ \\ ${ }^{1}$ Instituto de Agroquímica y Tecnología de Alimentos, Consejo Superior de Investigaciones \\ Científicas, PO Box 73, Burjassot, 46100 Valencia, Spain \\ ${ }^{2}$ Departament de Microbiología i Ecología, Facultat de Biología, Universitat de València, \\ Campus de Burjassot, 46100 Valencia, Spain
}

\begin{abstract}
Two bacterial strains, DSM $20253^{\top}$ and DSM 20254, isolated from rennin and regarded as causing cheese spoilage, were deposited in the DSMZ as Lactobacillus sp. by J. Stadhouders. The strains show $99.9 \% 16 \mathrm{~S}$ rRNA gene sequence similarity and have less than $94.3 \%$ similarity with any other species of the genus. Lactobacillus coryniformis is their closest phylogenetic neighbour. DNA-DNA hybridization experiments confirmed that the two strains are members of the same species with separate status within the genus Lactobacillus. The strains are homofermentative lactic acid bacteria and can be phenotypically and genotypically distinguished from their closest relatives. 16S rRNA gene-targeted specific primers were designed to enable PCR detection of the novel species. The name Lactobacillus rennini sp. nov. is proposed for the novel isolates, with strain CECT $5922^{\top}\left(=\right.$ DSM $20253^{\top}$ ) as the type strain.
\end{abstract}

The genus Lactobacillus, classified within the order 'Lactobacillales' in the last release of the Taxonomic Outline of the Prokaryotes (Garrity et al., 2004), includes 97 recognized species and novel taxa are continuously arising within this group. Species of the genus Lactobacillus are widespread in nature and can be found on plants or material of plant origin, in manure and man-made habitats such as sewage, in fermenting or spoiling food and also in association with the intestinal tracts and mucous membranes of man and many animals. The identification of novel isolates as separate species is not always possible by classical methods of physiological testing as they may share many phenotypic traits. At present, it is well established that, for an unequivocal identification, DNA and RNA analysis (hybridization or gene sequencing) form the basis of systematic taxonomy (Hammes \& Vogel, 1995).

Chenoll et al. (2003) obtained rDNA-RFLP profiles for 91 lactic acid bacteria (LAB) reference strains, including 45 species of Lactobacillus (of which 40 were type strains). The rDNA-RFLP profiles were derived from DdeI and HaeIII digests of the internal spacer region (ISR; ISR-DdeI, ISRHaeIII) and amplified rDNA restriction analysis (ARDRA) of the 16S rRNA gene digested with the same restriction

Published online ahead of print on 21 October 2005 as DOI 10.1099/ ijs.0.64021-0.

Abbreviations: 16S-ARDRA, amplified rDNA restriction analysis; ISR, internal spacer region; LAB, lactic acid bacteria.

A table detailing the reference strains used to test $L$. rennini-specific PCR primers and a dendrogram derived from 16S-ARDRA analyses are available as supplementary material in IJSEM Online. enzymes (16S-ARDRA-DdeI and 16S-ARDRA-HaeIII). Analysis of the rDNA-RFLP profiles revealed that some reference Lactobacillus strains, deposited as Lactobacillus sp., had unique rDNA-RFLP profiles (Chenoll et al., 2003). Based on 16S rRNA gene sequence analysis, it was suggested that these strains might represent novel species since the similarity values were clearly below $97 \%$. Two of these strains, CECT 5922 (=DSM 20253) and CECT 5923 (=DSM 20254) isolated from rennin and causing spoilage in cheese, were deposited at the DSMZ by J. Stadhouders. In 1967, Stadhouders and Veringa reported the presence of salt-tolerant lactobacilli multiplying in rennet that caused defects in Dutch cheese (Stadhouders \& Veringa, 1967). The spoiled cheeses showed many eyes and holes and, at a later stage of ripening, also showed small and large cracks and often developed a phenolic flavour. Lactobacilli were isolated from inefficiently filtered rennet and appeared to be related to species Lactobacillus casei and Lactobacillus plantarum, but differed from them, amongst other things, in their higher resistance to salt. The lactobacillus strains were able to persist in cheese for a long time during ripening and remained active by their breakdown of amino acids, which led to the production of off-flavours, acetic acid, ammonia and gas $\left(\mathrm{CO}_{2}\right)$. By using this contaminated rennet, it was demonstrated that cheese could be produced which showed the defects in question (Stadhouders \& Veringa, 1967).

The two strains, CECT $5922^{\mathrm{T}}$ and CECT 5923 , share $99 \cdot 9 \%$ $16 \mathrm{~S}$ rRNA gene sequence similarity and have less than $94 \cdot 3 \%$ similarity with any other species of the genus; their nearest phylogenetic neighbour is Lactobacillus coryniformis 
(Chenoll et al., 2003). In this work, phenotypic and genetic characterization of the two strains has confirmed that they belong to a novel species in the genus Lactobacillus.

Strains CECT $5922^{\mathrm{T}}$ and CECT 5923 were routinely grown in MRS (Oxoid) at $30^{\circ} \mathrm{C}$ under microaerophilic conditions and stored in liquid growth medium containing $20 \%(\mathrm{v} / \mathrm{v})$ glycerol at $-80^{\circ} \mathrm{C}$. Biochemical characterization of these strains, together with L. coryniformis subsp. torquens, was performed following standardized methods. All strains are Gram-positive and catalase-negative. Colonies of strains CECT $5922^{\mathrm{T}}$ and CECT 5923 grown on MRS agar plates for 3 days are very small (up to $1 \mathrm{~mm}$ in diameter), grey, smooth, circular and with entire edges. Cells are nonmotile and non-spore-forming, rod-shaped, approximately $2-4 \times 1 \mu \mathrm{m}$ in size, though occasionally longer cells are observed, and occur mainly singly or in pairs. Strains CECT $5922^{\mathrm{T}}$ and CECT 5923 grow at 13,25 and $37^{\circ} \mathrm{C}$, but not at 4 or $45^{\circ} \mathrm{C}$, and at $\mathrm{pH} 3 \cdot 7,4 \cdot 5$ and $\mathrm{pH} 8 \cdot 0$. Both strains grow in medium with 5 and $10 \%(\mathrm{w} / \mathrm{v}) \mathrm{NaCl}$. Strains CECT $5922^{\mathrm{T}}$ and CECT 5923 do not produce gas from glucose or gluconate as examined with Durham tubes, revealing their homofermentative metabolism. Production of ammonia from arginine, determined as described by Kato et al. (2000), is negative. The lactic acid isomer, determined enzymically using the DL-lactate test kit (Boehringer Mannheim), is L(D).

Carbohydrate fermentation patterns and aesculin hydrolysis were evaluated using API 50 CHL galleries (bioMérieux) according to the manufacturer's instructions. Strains were incubated at $30^{\circ} \mathrm{C}$ for $48 \mathrm{~h}$. Strains CECT $5922^{\mathrm{T}}$ and CECT 5923 show similar fermentation profiles, but strain CECT $5922^{\mathrm{T}}$ also ferments D-mannitol, maltose, lactose and sucrose and is able to hydrolyse aesculin. Differential phenotypic traits are shown in Table 1 . L. coryniformis subsp. torquens CECT $4129^{\mathrm{T}}$ differed from the novel strains in its ability to ferment 2-ketogluconate and in its inability to ferment L-arabinose, D-ribose or D-xylose and its inability to hydrolyse aesculin (Table 1).

As stated in the online catalogue of DSMZ (http://www. dsmz.de), the cell-wall peptidoglycan of strains CECT $5922^{\mathrm{T}}$ and CECT 5923 is L-Lys-D-Asp.

The 16S rRNA gene sequences of about 1500 bp of strains CECT $5922^{\mathrm{T}}$ (GenBank accession number AJ576007) and CECT 5923 (GenBank accession number AJ576008) were obtained in a previous study (Chenoll et al., 2003). Comparative analysis was performed with the full dataset of more than 22000 reference sequences from the ARB database (http://www.arb-home.de) using the ARB program package (Ludwig et al., 2004). The ARB tools were used for automated sequence alignment and tree reconstruction. The alignment was checked visually and corrected manually using the sequence editor ARB_EDIT. Sequence similarity values were calculated by comparing nucleotides at corresponding positions and the high similarity between strains CECT $5922^{\mathrm{T}}$ and CECT $5923(99 \cdot 9 \%)$ was confirmed. A closely
Table 1. Phenotypic traits that differ between Lactobacillus rennini and its closest phylogenetic neighbour, $L$. coryniformis

For comparative purposes, some other homofermentative lactobacilli are included. Species: $1, L$. rennini sp. nov. (this study); $2 \mathrm{a}, L$. coryniformis subsp. coryniformis (Abo-Elnaga \& Kandler, 1965); 2b, L. coryniformis subsp. torquens (this study); 3, L. fornicalis (Dicks et al., 2000); 4, L. fuchuensis (Sakala et al., 2002); 5, L. kitasatonis (Mukai et al., 2003); 6, L. kunkeei (Edwards et al., 1998); 7, L. suntoryeus (Cachat \& Priest, 2005). +, All strains positive; -, all strains negative; $\mathrm{P}, 11-89 \%$ of the strains are positive; $\mathrm{W}$, weak reaction; ND, no data.

\begin{tabular}{|c|c|c|c|c|c|c|c|c|}
\hline Characteristic & 1 & $2 a$ & $2 b$ & 3 & 4 & 5 & 6 & 7 \\
\hline \multicolumn{9}{|l|}{ Gas production from: } \\
\hline Gluconate & - & + & + & - & - & - & - & - \\
\hline Lactate isomer produced & $\mathrm{L}(\mathrm{D})$ & $\mathrm{D}(\mathrm{L})$ & $\mathrm{D}$ & DL & $\mathrm{L}(\mathrm{D})$ & DL & $\mathrm{L}$ & ND \\
\hline \multicolumn{9}{|l|}{ Growth at: } \\
\hline $5^{\circ} \mathrm{C}$ & - & $\mathrm{ND}$ & - & - & + & - & - & - \\
\hline $15^{\circ} \mathrm{C}$ & $\mathrm{W}$ & + & + & - & ND & - & + & - \\
\hline $45^{\circ} \mathrm{C}$ & - & - & - & - & - & + & - & + \\
\hline \multicolumn{9}{|l|}{ Acid production from: } \\
\hline$N$-Acetylglucosamine & + & + & + & ND & + & ND & - & + \\
\hline Amygdalin & - & - & - & + & + & - & - & + \\
\hline L-Arabinose & $\mathrm{W}$ & - & - & - & - & - & - & - \\
\hline Arbutin & - & ND & - & ND & + & - & - & + \\
\hline D-Cellobiose & - & - & - & + & + & $\mathrm{P}$ & - & - \\
\hline D-Galactose & $\mathrm{W}$ & + & + & + & + & + & - & $\mathrm{P}$ \\
\hline D-Mannose & + & + & + & + & + & + & - & + \\
\hline D-Melezitose & - & - & - & + & - & - & - & - \\
\hline L-Rhamnose & - & + & - & - & + & ND & - & - \\
\hline D-Ribose & $+(\mathrm{W})^{*}$ & - & - & + & + & - & - & - \\
\hline D-Sorbitol & - & $\mathrm{P}$ & - & + & - & - & - & - \\
\hline Starch & - & ND & - & - & + & $\mathrm{ND}$ & - & $\mathrm{P}$ \\
\hline D-Trehalose & - & - & - & + & + & - & - & - \\
\hline D-Xylose & $\mathrm{W}$ & - & - & - & + & - & - & - \\
\hline
\end{tabular}

${ }^{\star}$ Result for type strain is in parentheses.

related sequence, submitted to EMBL by D. Ouwerkerk \& A. V. Klieve in 2000 (GenBank accession number AF316586), has $99 \cdot 8 \%$ similarity with both novel strains. This sequence is documented as belonging to a feedlot manure isolate, YE07, and identified as Lactobacillus sp. However, strains CECT $5922^{\mathrm{T}}$ and CECT 5923 had less than $94 \cdot 3 \%$ sequence similarity to any species with validly published names. The phylogenetic tree constructed using the neighbour-joining method shows that $L$. coryniformis subsp. torquens and L. coryniformis subsp. coryniformis are the closest phylogenetic neighbours to the novel strains (Fig. 1). Following the recommendations of Ludwig et al. (1998), alternative treeing methods (maximum-parsimony and maximum-likelihood) were used which confirmed the position of CECT $5922^{\mathrm{T}}$ and CECT 5923 in the vicinity of L. coryniformis and Lactobacillus bifermentans (data not shown). 


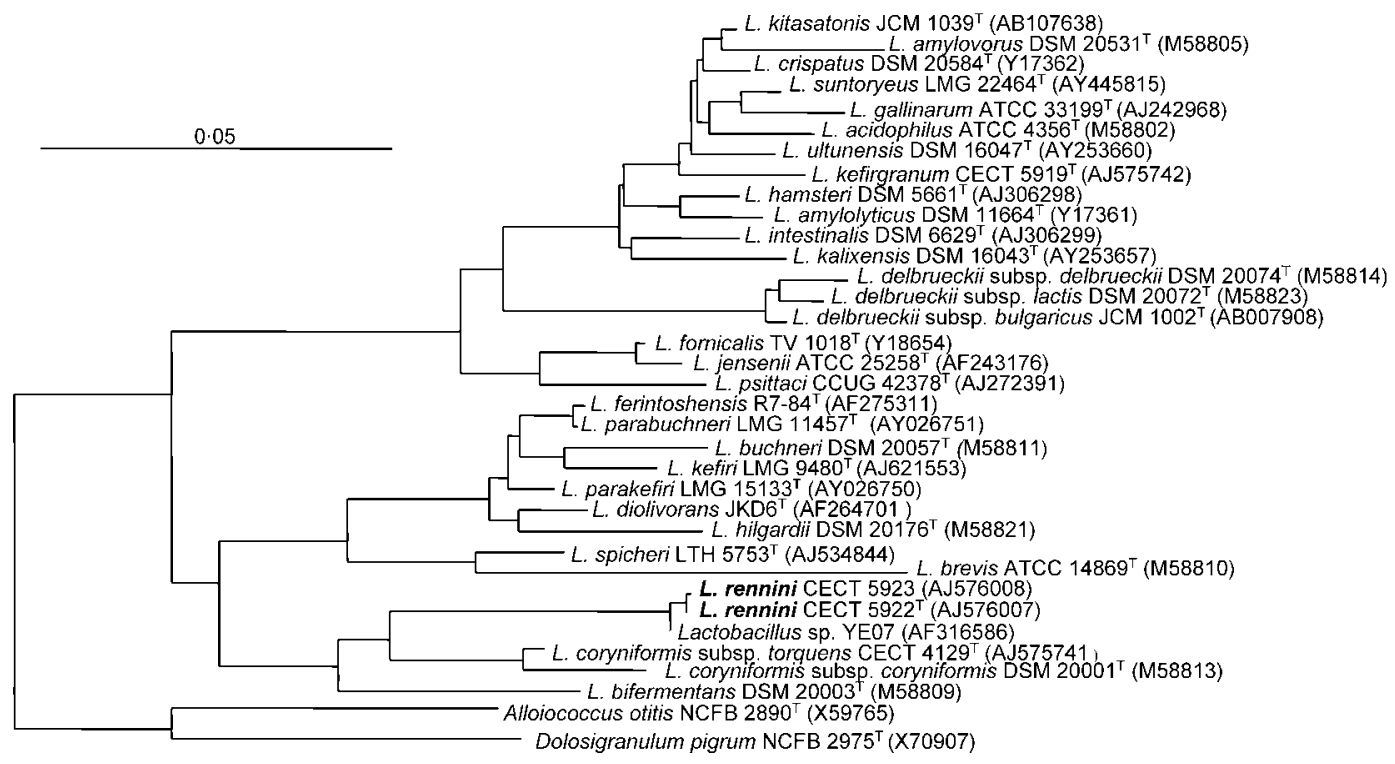

Fig. 1. Phylogenetic tree constructed using the neighbour-joining method based on 16S rRNA gene sequences. Lactobacillus rennini sp. nov. strains CECT $5922^{\top}$ and CECT 5923 and sequence AF316586 (corresponding to a feedlot manure isolate, YE07) are close to L. coryniformis. Bar, $5 \%$ nucleotide substitution.

Genotypic characterization by rDNA-RFLP profile analysis revealed that strains CECT $5922^{\mathrm{T}}$ and CECT 5923 share 16S-ARDRA-DdeI, ISR-DdeI and ISR-HaeIII profiles. The strains differ only in one band in the 16S-ARDRA-HaeIII profile, due to one nucleotide difference in a restriction site. Compared with the phylogenetically closest species they showed unique profiles, apart from the ISR-HaeIII-RFLP profile (Chenoll et al., 2003) which was similar to those of Lactobacillus parabuchneri and L. coryniformis subsp. torquens (see Supplementary Fig. S1 in IJSEM Online).

DNA-DNA hybridization experiments were performed as described by Ziemke et al. (1998) with DNA of strains CECT $5922^{\mathrm{T}}$, CECT 5923 and L. coryniformis subsp. torquens CECT $4129^{\mathrm{T}}$. The reference DNA was that of strain CECT $5922^{\mathrm{T}}$ and the results are expressed as mean percentage values based on three independent hybridization experiments. The relative binding ratio values of strain CECT $5922^{\mathrm{T}}$ to strain CECT 5923 were always above $80 \%$ (mean 86.5, max. 93, min. 80, SD 9.2, $n=3$ ). The hybridization values between strain CECT $5922^{\mathrm{T}}$ and L. coryniformis subsp. torquens CECT $4129^{\mathrm{T}}$ were always below $60 \%$ (mean $55 \cdot 5$, max. 60 , min. $46 \cdot 3$, SD $6 \cdot 4, n=3$ ). All these results confirm that strains CECT $5922^{\mathrm{T}}$ and CECT 5923 are members of the same species, with separate status within the genus Lactobacillus.

Species-specific primers targeted to the $16 \mathrm{~S}$ rRNA gene for the novel strains were designed using the appropriate ARB software package tool (Ludwig et al., 2004). Following the nomenclature of Alm et al. (1996), they are S-S-Lren-0060a-S (5'-GTCGCACGCACAACTGTT-3') as the sense primer and S-S-Lren-0175-a-A (5'-GTCGCGTATTTCTATGCG- $\left.3^{\prime}\right)$ as the antisense primer. The primers were proved to be specific by testing in silico using the BLAST tool. In addition, specificity was tested in vitro by PCR amplification of $52 \mathrm{LAB}$ reference strains (seven Carnobacterium species, 36 Lactobacillus species and nine Leuconostoc species). The strains used are listed in Supplementary Table S1 (see IJSEM Online). PCR was carried out at an annealing temperature of $56^{\circ} \mathrm{C}$, as described by Macián et al. (2004). The specific fragment of 133 bp was only amplified from strains CECT $5922^{\mathrm{T}}$ and CECT 5923.

Based on the data reported here, strains CECT $5922^{\mathrm{T}}$ and CECT 5923 are members of a novel species within the genus Lactobacillus. They show phenotypic characters that distinguish them from other homofermentative lactobacillus species and L. coryniformis, their closest phylogenetic relative (Table 1), as well as genotypic traits that enable them to be differentiated by any of the following rDNARFLP profiles: 16S-ARDRA-DdeI, 16S-ARDRA-HaeIII, ISR-DdeI or ISR-HaeIII (see Supplementary Fig. S1). We propose the name Lactobacillus rennini sp. nov. for the two novel strains isolated from rennin by J. Stadhouders. The type strain is CECT $5922^{\mathrm{T}}\left(=\mathrm{DSM} 20253^{\mathrm{T}}\right)$ and CECT 5923 (=DSM 20254) is a reference strain.

\section{Description of Lactobacillus rennini sp. nov.}

Lactobacillus rennini (ren.ni' ni. N.L. n. renninum rennin, an enzyme that coagulates milk and is used in making cheese; N.L. gen. n. rennini of rennin).

Cells are rod-shaped, $1 \mu \mathrm{m}$ wide by $2-4 \mu \mathrm{m}$ long, Grampositive, catalase-negative, non-spore-forming and nonmotile. They are found singly and in pairs. Grows better in 
MRS broth than on agar plates and under anaerobic conditions. After 3 days of incubation in MRS agar at $30^{\circ} \mathrm{C}$, colonies are small (up to $1 \mathrm{~mm}$ in diameter), circular, translucent and grey. Grows at $13^{\circ} \mathrm{C}$, but not at 4 or $45^{\circ} \mathrm{C}$. Homofermentative. No gas is produced from glucose or gluconate. Arginine is not hydrolysed. Both D- and L-lactic acid are produced. Strains ferment L-arabinose, D-ribose, Dxylose, D-galactose, D-glucose, D-fructose, D-mannose and $\mathrm{N}$-acetylglucosamine. Does not ferment glycerol, erythritol, D-arabinose, L-xylose, adonitol, methyl $\beta$-xyloside, Lsorbose, L-rhamnose, dulcitol, inositol, sorbitol, methyl $\alpha$ D-mannoside, methyl $\alpha$-D-glucoside, amygdalin, arbutin, salicin, D-cellobiose, melibiose, D-trehalose, inulin, melezitose, D-raffinose, starch, glycogen, xylitol, gentibiose, D-turanose, D-lyxose, D-tagatose, D-fucose, L-fucose, D-arabitol, L-arabitol, gluconate, 2-ketogluconate or 5ketogluconate. The type strain also ferments D-mannitol, maltose, lactose and sucrose and hydrolyses aesculin. Peptidoglycan type is L-Lys-D-Asp.

The type strain, CECT $5922^{\mathrm{T}}\left(=\right.$ DSM $20253^{\mathrm{T}}$ ), was isolated from rennin by J. Stadhouders. Strain CECT 5923 (=DSM 20254), also isolated from rennin by J. Stadhouders, is a reference strain.

\section{Acknowledgements}

The work has been supported by the Comisión Interministerial de Ciencia y Tecnología (CICYT) grant AGL2000-1462. E. C. is the recipient of a PhD fellowship I3P-BPD2001-1 from the Consejo Superior de Investigaciones Científicas (CSIC). We thank CECT for reference cultures. Thanks are due to J. P. Euzéby for advising on the etymology of the new taxa.

\section{References}

Abo-Elnaga, I. G. \& Kandler, O. (1965). Zur Taxonomie der Gattung Lactobacillus Beijerinck. I. Das Subgenus Streptobacterium Orla-Jensen. Zentralbl Bakteriol Parasitkd Infektionskr Hyg 119, 1-36 (in German).

Alm, E. W., Oerther, D. B., Larsen, N., Stahl, D. A. \& Raskin, L. (1996). The oligonucleotide probe database. Appl Environ Microbiol 62, 3557-3559.
Cachat, E. \& Priest, F. G. (2005). Lactobacillus suntoryeus sp. nov., isolated from malt whisky distilleries. Int J Syst Evol Microbiol 55, 31-34.

Chenoll, E., Macián, M. C. \& Aznar, R. (2003). Identification of Carnobacterium, Lactobacillus, Leuconostoc and Pediococcus by rDNAbased techniques. Syst Appl Microbiol 26, 546-556.

Dicks, L. M. T., Silvester, M., Lawson, P. A. \& Collins, M. D. (2000). Lactobacillus fornicalis sp. nov., isolated from the posterior fornix of the human vagina. Int J Syst Evol Microbiol 50, 1253-1258.

Edwards, C. G., Haag, K. M., Collins, M. D., Hutson, R. A. \& Huang, Y. C. (1998). Lactobacillus kunkeei sp. nov.: a spoilage organism associated with grape juice fermentations. J Appl Microbiol 84, 698-702.

Garrity, G. M., Bell, J. A. \& Lilburn, T. G. (2004). Taxonomic outline of the Prokaryotes. In Bergey's Manual of Systematic Bacteriology, 2nd edn, release 5.0. New York: Springer. DOI: 10.1007/bergeysoutline200405

Hammes, W. P. \& Vogel, R. F. (1995). The genus Lactobacillus. In The Lactic Acid Bacteria, vol. 2, The Genera of Lactic Acid Bacteria, pp. 19-54. Edited by B. J. B. Wood \& W. H. Holzapfel. London: Blackie Academic \& Professional.

Kato, Y., Sakala, R. M., Hayashidani, H., Kiuchi, A., Kaneuchi, C. \& Ogawa, M. (2000). Lactobacillus algidus sp. nov., a psychrophilic lactic acid bacterium isolated from vacuum-packaged refrigerated beef. Int J Syst Evol Microbiol 50, 1143-1149.

Ludwig, W., Strunk, O., Klugbauer, S., Klugbauer, N., Weizenegger, M., Neumaier, J., Bachleitner, M. \& Schleifer, K. H. (1998). Bacterial phylogeny based on comparative sequence analysis. Electrophoresis 19, 554-568.

Ludwig, W., Strunk, O., Westram, R. \& 29 other authors (2004). ARB: a software environment for sequence data. Nucleic Acids Res 32, 1363-1371.

Macián, M. C., Chenoll, E. \& Aznar, R. (2004). Simultaneous detection of Carnobacterium and Leuconostoc in meat products by multiplex PCR. J Appl Microbiol 97, 384-394.

Mukai, T., Arihara, K., Ikeda, A., Nomura, K., Suzuki, F. \& Ohori, H. (2003). Lactobacillus kitasatonis sp. nov., from chicken intestine. Int J Syst Evol Microbiol 53, 2055-2059.

Sakala, R. M., Kato, Y., Hayashidani, H., Murakami, M., Kaneuchi, C. \& Ogawa, M. (2002). Lactobacillus fuchuensis sp. nov., isolated from vacuum-packaged refrigerated beef. Int J Syst Evol Microbiol 52, 1151-1154.

Stadhouders, J. \& Veringa, H. A. (1967). Texture and flavour defects in cheese caused by bacteria from contaminated rennet. Neth Milk \& Dairy J 21, 192-207.

Ziemke, F., Höfle, M. G., Lalucat, J. \& Rosselló-Mora, R. (1998). Reclassification of Shewanella putrefaciens Owen's genomic group II as Shewanella baltica sp. nov. Int J Syst Bacteriol 48, 179-186. 